\title{
Differences in the binding, internalization and catabolism of low-density lipoprotein between normal human $T$ and $B$ lymphocytes
}

\author{
Ajit SANGHVI and Vijay WARTY \\ Department of Pathology, University of Pittsburgh School of Medicine, Pittsburgh, PA 15261, U.S.A.
}

(Received 21 August 1984/Accepted 12 December 1984)

\begin{abstract}
Studies in human peripheral blood $B$ and $T$ lymphocytes show that high-affinity binding of low-density lipoprotein (LDL) to the cell surface receptor and the kinetics of binding are comparable between B and T lymphocytes, but the internalization of receptor-bound LDL in B cells appears deficient. Yet, the fraction of internalized LDL degraded by both $\mathrm{B}$ and $\mathrm{T}$ lymphocytes is of similar magnitude. Moreover, the lysosomal acid cholesterol ester hydrolase and acyl-CoA : cholesterol acyltransferase activities in B cell were about one-third of those in T lymphocytes. These data suggest deficient LDL catabolism in B lymphocytes relative to that in $\mathrm{T}$ lymphocytes.
\end{abstract}

Studies in human peripheral blood lymphocytes (Ho et al., 1976) have shown that LDL metabolism in these cells occurs via the high-affinity receptor pathway first described in cultured human fibroblasts (Goldstein \& Brown, 1974). In lymphocytes, however, this pathway was delineated using the mixed (unseparated $T$ and $B$ ) population of cells. Recently, we have shown (Sanghvi et al., 1981a; Sanghvi \& Warty, 1982) that there are important differences in cholesterol metabolism among the two major lymphocyte subpopulations, the thymus-derived $T$ and the bursa-equivalent $B$ cells. For example, following incubation in lipoproteindeficient serum, there is a significant increase in 3hydroxy-3-methylglutaryl-CoA reductase activity and cholesterol synthesis in both $B$ and $T$ lymphocytes from healthy subjects, but this increase is four times greater in $T$ cells relative to B cells. Moreover, in contrast to $\mathrm{T}$ cells, the increased B-cell 3hydroxy-3-methylglutaryl-CoA reductase activity and cholesterol synthesis could not be suppressed by increasing concentrations of LDL in the medium. These results implied that there was in B lymphocytes a probable defect in one or more steps concerned with LDL metabolism, which occurs via the high-affinity receptor pathway. Studies conducted in our laboratory to investigate further these differences indicate that, in B cells compared with $T$ cells, cholesterol metabolism appears to be

Abbreviations used: LDL, low-density lipoprotein; HDL, high-density lipoprotein; ACEH, acid cholesterol ester hydrolase; ACAT, acyl-CoA : cholesterol acyltransferase. at a step-down level beginning with defective internalization of cell surface bound LDL-receptor complex and reduced levels of ACEH and ACAT activities.

\section{Experimental}

Materials

$\left[7-{ }^{3} \mathrm{H}\right] \mathrm{Cholesterol}(16 \mathrm{Ci} / \mathrm{mmol}), \quad\left[2-{ }^{14} \mathrm{C}\right]$ acetic acid, sodium salt, $\left[1^{-14} \mathrm{C}\right]$ oleic acid $(57 \mathrm{mCi} / \mathrm{mmol})$, $\left[9,10-{ }^{3} \mathrm{H}\right]$ oleic acid $(16 \mathrm{Ci} / \mathrm{mmol})$, cholesteryl [1${ }^{14} \mathrm{C}$ ]oleate $\left(56 \mathrm{mCi} / \mathrm{mmol}\right.$ ) and $\mathrm{Na}^{125} \mathrm{I}$ (carrier free in $0.1 \mathrm{M}-\mathrm{NaOH}$ ) were obtained from New England Nuclear Corp. Sodium heparin and bovine serum albumin (essentially fatty-acid-free) were obtained from Sigma Chemical Co.; 25-hydroxycholesterol was from Steraloids. Sodium oleate, non-radioactive cholesterol and cholesteryl oleate were purchased from Supelco Inc. Culture media and antibiotics were obtained from Gibco. All other reagents and supplies were from Fisher Scientific.

\section{Lipoproteins}

Human LDL ( $d$ 1.019-1.063), HDL ( $d$ 1.063$1.215)$ and lipoprotein-deficient serum $(d>1.215)$ were prepared from blood collected in $0.1 \%$ EDTA from healthy subjects who had fasted overnight. Lipoproteins were fractionated by sequential flotation in a Beckman preparative ultracentrifuge according to Havel et al. (1955) and used within 10 days following isolation. Each experiment employed freshly obtained lipoproteins. ${ }^{125}$ I-labelled LDL was prepared by using a modification of the ICl method of MacFarlane (1958), as described by 
Bilheimer et al. (1972). Less than $3 \%$ of the radiolabel was found in lipid as determined by chloroform/methanol $(2: 1, \mathrm{v} / \mathrm{v})$ treatment and $96 \%$ of radioactivity was recovered in the trichloroacetic acid precipitate. ${ }^{125} \mathrm{I}-\mathrm{LDL}$ was stored at $4^{\circ} \mathrm{C}$ and it retained full activity for at least 4 weeks. For experimental purposes ${ }^{125}$ I-LDL was diluted with native LDL to give the final specific radioactivity indicated in legends to figures. Protein determinations were performed by the Bradford (1976) method.

Cells

Peripheral blood mononuclear cells were isolated as previously described (Sanghvi et al., 1981a) from approx. $100 \mathrm{ml}$ of blood drawn for each experiment from each of the healthy subjects (three males, two females) with no history of metabolic disorders.

The monocyte content of the mononuclear cell preparations was depleted by the method of Jerrells et al. (1980). Following this treatment, the monocyte contamination in each preparation of $\mathbf{B}$ and $\mathrm{T}$ cells did not exceed $3 \%$, as measured by immunofluorescence using monoclonal antibodies (Wornke \& Levy, 1.980).

Both $B$ and $T$ cell viability was assessed three times for each experiment by dye exclusion: (i) immediately following isolation of cells, (ii) after incubation in medium with $10 \%$ lipoprotein-deficient serum or $1 \%$ bovine serum albumin, and (iii) at the end of each experiment. At each point, cells were washed three times with RPMI buffer not containing protein before the dye exclusion test was performed. Two different dyes, Trypan Blue and ethidium bromide, were used; of the two, the test with ethidium bromide is thought to be highly sensitive (Rabin \& Rosenthal, 1984). In each case, at least $90 \%$ of the recovered cells were found to be viable. In addition, after $44 \mathrm{~h}$ incubation of cells in lipoprotein-deficient serum, incorporation of ${ }^{3} \mathrm{H}$ labelled valine into cell protein of both $B$ and $T$ cells was measured over a period of $8 \mathrm{~h}$ in the presence of LDL $(6 \mu \mathrm{g} / \mathrm{ml}$ of medium), with a pulse of $\left[{ }^{3} \mathrm{H}\right]$ valine every $2 \mathrm{~h}$. This was done to ensure that there was equivalent viability of $T$ and $B$ lymphocytes during these times, as would be signified by equivalent incorporation of $\left[{ }^{3} \mathrm{H}\right]$ valine into cell protein. The data obtained indicated that $\left[{ }^{3} \mathrm{H}\right]-$ valine incorporation into cell protein of $\mathrm{T}$ and $\mathrm{B}$ cells over the $8 \mathrm{~h}$ period was $(27 \pm 1.5) \times 10^{4}$ and $(25 \pm 2.0) \times 10^{4}$ d.p.m. (means \pm S.D., $\left.n=4\right) / \mathrm{mg}$ of protein, respectively. Incubated cells were morphologically identifiable as lymphocytes $(90 \%)$ by differential counts.

$B$ and $T$ lymphocytes were separated by the shee $_{r}$ red blood cells erythrocyte-rosetting technique under conditions described previously
(Sanghvi et al., 1981a). B cell preparations were characterized by the immunobead rosette test (Wybran et al., 1972) and immunofluorescence test (Chao \& Yokoyama, 1977); the purity of different B cell preparations ranged between 88 and $94 \%$. T cell purity was assessed by using the erythrocyterosetting technique (Kaplan \& Clark, 1968) and was found to be $90-94 \%$. Further characterization of the $\mathrm{T}$ cell fraction by a monoclonal antibody method (Kaplan \& Clark, 1968) showed 92\% purity. Separated $T$ and B lymphocytes were routinely incubated in RPMI-1640 medium containing 100 units of penicillin $/ \mathrm{ml}, 100 \mu \mathrm{g}$ of streptomycin $/ \mathrm{ml}$ and $10 \%$ lipoprotein-deficient serum. Incubations were performed for $44 \mathrm{~h}$ at $37^{\circ} \mathrm{C}$ in a humidified incubator equilibrated with $\mathrm{CO}_{2}$ /air (1:19) (Sanghvi et al., 1981a). When 1\% bovine serum albumin was substituted for lipoproteindeficient serum in the culture medium, the stimulation of cellular cholesterol synthesis obtained in $22 \mathrm{~h}$ in $1 \%$ albumin was of the same magnitude as in $10 \%$ lipoprotein-deficient serum medium for $44 \mathrm{~h}: 514 \pm 16$ and $504 \pm 18$ (means \pm S.D. $n=4$ ) pmol of $\left[{ }^{14} \mathrm{C}\right]$ acetate converted to $\left[{ }^{14} \mathrm{C}\right]$ cholesterol $/ \mathrm{h}$ per $\mathrm{mg}$ of protein in albumin and lipoprotein-deficient serum, respectively.

The content of free and esterified cholesterol in separated B and T lymphocytes was measured with a g.c.-m.s. procedure described previously (Sanghvi et al., 1981b).

Each of the following experiments was conducted with cells from single individuals. Therefore, sufficient blood from each donor was obtained to provide the required number of cells. In no instance did studies of cholesterol synthesis, enzyme activities, binding, internalization and degradation of lipoprotein reported here utilize pooled cells from different donors. This was done in order to prevent the mixed lymphocyte reaction which may occur and which, in turn, might partially explain the observed differences between $B$ and $T$ cells had this precaution not been taken.

Incorporation of $\left[2-{ }^{14} \mathrm{C}\right]$ acetate into cholesterol in isolated $T$ and $B$ lymphocytes was carried out as previously described (Sanghvi et al., 1981a).

\section{$A C A T$ and $A C E H$ activities}

Incorporation of $\left[1^{-14} \mathrm{C}\right]$ oleic acid into cholesterol $\left[{ }^{14} \mathrm{C}\right]$ oleate was studied as a measure of ACAT activity. The assays were performed under conditions exactly as described by Goldstein $e t$ al. (1974). Average results of duplicate assays are expressed as nmol of $\left[{ }^{14} \mathrm{C}\right]$ oleic acid incorporated into cholesteryl $\left[{ }^{14} \mathrm{C}\right]$ oleate/h per $\mathrm{mg}$ of protein.

ACEH activity was determined in cell homogenates by using the procedure of Haley et al. (1980). Results are expressed as nmol of cholesteryl 
$\left[{ }^{1+} \mathrm{C}\right]$ oleate hydrolysed/mg of protein as a function of time in min.

\section{Measurement of the amounts of heparin-releasable ${ }^{125}$ I-LDL, heparin-resistant ${ }^{125}$ I-LDL and ${ }^{125}$ I-LDL degraded by intact $T$ and $B$ lymphocytes at $37^{\circ} \mathrm{C}$}

The ability of sulphated glycosaminoglycans to form soluble complexes with LDL has been utilized by Goldstein et al. (1976) to study the properties and kinetics of binding of LDL to its receptor on the cell surface and the subsequent process of cellular uptake of the receptor-bound LDL by fibroblasts. We used this same approach to study similar phenomena in $\mathrm{T}$ and $\mathrm{B}$ lymphocytes. In this method, heparin is able to release ${ }^{125} \mathrm{I}-\mathrm{LDL}$ bound to its receptor on the cell surface. The amount of ${ }^{125} \mathrm{I}-\mathrm{LDL}$ that resists the heparin treatment, and remains associated with the cell, equals the internalized ${ }^{125} \mathrm{I}$-LDL.

Cells were incubated for $22 \mathrm{~h}$ in RPMI 1640 growth medium containing $1 \%$ bovine albumin, following which they were harvested in fresh medium with albumin at a concentration of $2 \times 10^{6}$ cells $/ \mathrm{ml}$. Portions $(1 \mathrm{ml})$ of cell suspension were placed in different wells and incubated with concentrations of ${ }^{125} \mathrm{I}-\mathrm{LDL}$ which ranged from 0 to $200 \mu \mathrm{g} / \mathrm{ml}$ for a period of $5 \mathrm{~h}$ at $37^{\circ} \mathrm{C}$. The determination of heparin-releasable and -resistant ${ }^{125} \mathrm{I}$ LDL was then performed as described by Goldstein et al. (1976).

In order to determine the amount of ${ }^{125}$ I-LDL degraded by the cells in a $5 \mathrm{~h}$ period, a sample of cell-free medium was treated with $10 \%(w / v)$ trichloroacetic acid to remove precipitable proteins. Free iodine was removed by treating the acidsoluble fraction with $\mathrm{KI}$ and $\mathrm{H}_{2} \mathrm{O}_{2}$, followed by extraction with chloroform. The aqueous phase was counted for ${ }^{125}$ I activity which is a measure of the amount of acid-soluble material released by the cells into the medium (Goldstein et al., 1976).

In all of the above experiments, the amount of ${ }^{125} \mathrm{I}$-LDL nonspecifically associated with the cell surface was measured in a simultaneous series of experiments conducted in the presence and absence of a 25-fold excess of unlabelled LDL at each concentration of labelled LDL used.

\section{Results}

The rates of cholesterol synthesis in separated B and $T$ lymphocytes were similar immediately following their isolation from blood $(\mathrm{T}, 17.8 \pm 0.7 ; \mathrm{B}$, $14.5 \pm 1.4 \mathrm{pmol}$ of $\left[{ }^{14} \mathrm{C}\right]$ acetate $/ \mathrm{h}$ per $\mathrm{mg}$ of protein; means \pm S.E.M., $n=5$ ). However, they were more than 5-fold higher in T cells relative to $B$ cells following incubation of cells in $10 \%$ lipoprotein-deficient serum for $44 \mathrm{~h}(\mathrm{~T}, 529 \pm 48.7 \mathrm{pmol} / \mathrm{h}$ per $\mathrm{mg}$ of protein ; B, $96 \pm 24.2$; means \pm S.E.M., $n=5$ ). More- over, in contrast to $T$ cells, the increased rate of cholesterol synthesis in B cells could not be suppressed by increasing amounts of LDL in the medium (up to $650 \mu \mathrm{g} / \mathrm{ml}$ ). These data are consistent with our previous observations (Sanghvi et al., 1981 $a$; Sanghvi \& Warty, 1982) and they suggest that one or more steps in the LDL-receptor pathway of B lymphocytes may be defective or suboptimal.

The rate-limiting step in the LDL pathway is the binding of LDL to a specific high-affinity receptor on the cell surface (Goldstein \& Brown, 1974). Fig. 1(a) shows specific high-affinity binding of ${ }^{125} \mathrm{I}$-LDL to its receptor in T and B lymphocytes obtained from three subjects, following a $22 \mathrm{~h}$ preincubation of cells in $1 \%$ albumin. These data indicate essentially identical ${ }^{125} \mathrm{I}-\mathrm{LDL}$ binding and saturation kinetics for both $\mathrm{T}$ and $\mathrm{B}$ cells. The apparent dissociation constant, $K_{\mathrm{D}}$ (Gal et al., 1982), calculated from the double-reciprocal plot of these data is quite similar at $4.4 \pm 0.1$ and $3.6 \pm 0.2 \mu \mathrm{g} / \mathrm{ml}$ (means \pm S.D., $n=3$ ) for $\mathrm{T}$ and $\mathrm{B}$ cells, respectively. In both instances, the ${ }^{125} \mathrm{I}-\mathrm{LDL}$ binding to its receptor appears to reach saturation at about $50 \mu \mathrm{g} / \mathrm{ml}$.

The cellular uptake and degradation of ${ }^{125} \mathrm{I}$ LDL by B lymphocytes in steady state appears to involve a saturable high-affinity component (Figs. $1 b$ and $1 c$ respectively). More importantly, however, the absolute amounts of ${ }^{125}$ I-LDL taken up and degraded by $\mathbf{B}$ cells are quite small compared with $\mathrm{T}$ cells.

Ho et al. (1976) and Brown \& Goldstein (1976) have demonstrated that in mixed lymphocytes and human fibroblasts, unlabelled LDL is far more effective in competing for receptor-bound ${ }^{125} \mathrm{I}$ LDL than unlabelled HDL; that is, the receptor is specific for LDL. Consistent with these reports, our experiments, conducted according to Brown \& Goldstein (1976), showed that $50 \%$ reduction in the cell surface binding of ${ }^{125} \mathrm{I}$-LDL occurred at about $25 \mu \mathrm{g}$ of unlabelled $\mathrm{LDL} / \mathrm{ml}$ for both T and B cells. The corresponding concentration of unlabelled HDL required to achieve $50 \%$ reduction in the binding of ${ }^{125} \mathrm{I}-\mathrm{LDL}$ was more than $400 \mu \mathrm{g} / \mathrm{ml}$ for $T$ lymphocytes and was even greater in the case of B lymphocytes.

Moreover, the LDL receptor activity of normal fibroblasts and mixed lymphocytes is shown to be subject to feedback regulation by LDL or a mixture of sterols (Brown \& Goldstein, 1975). The LDL receptor activity in B lymphocytes was found to be susceptible to such a feedback regulation in the same manner as in $\mathrm{T}$ lymphocytes. Thus, $\mathrm{T}$ and $\mathrm{B}$ lymphocytes bound only 17 and $29 \%$ of ${ }^{125}$ I-LDL, respectively, in the presence of $10 \mu \mathrm{g}$ of unlabelled LDL relative to that in its absence. ${ }^{125}$ I-LDL binding to both cell types was almost totally abolished 

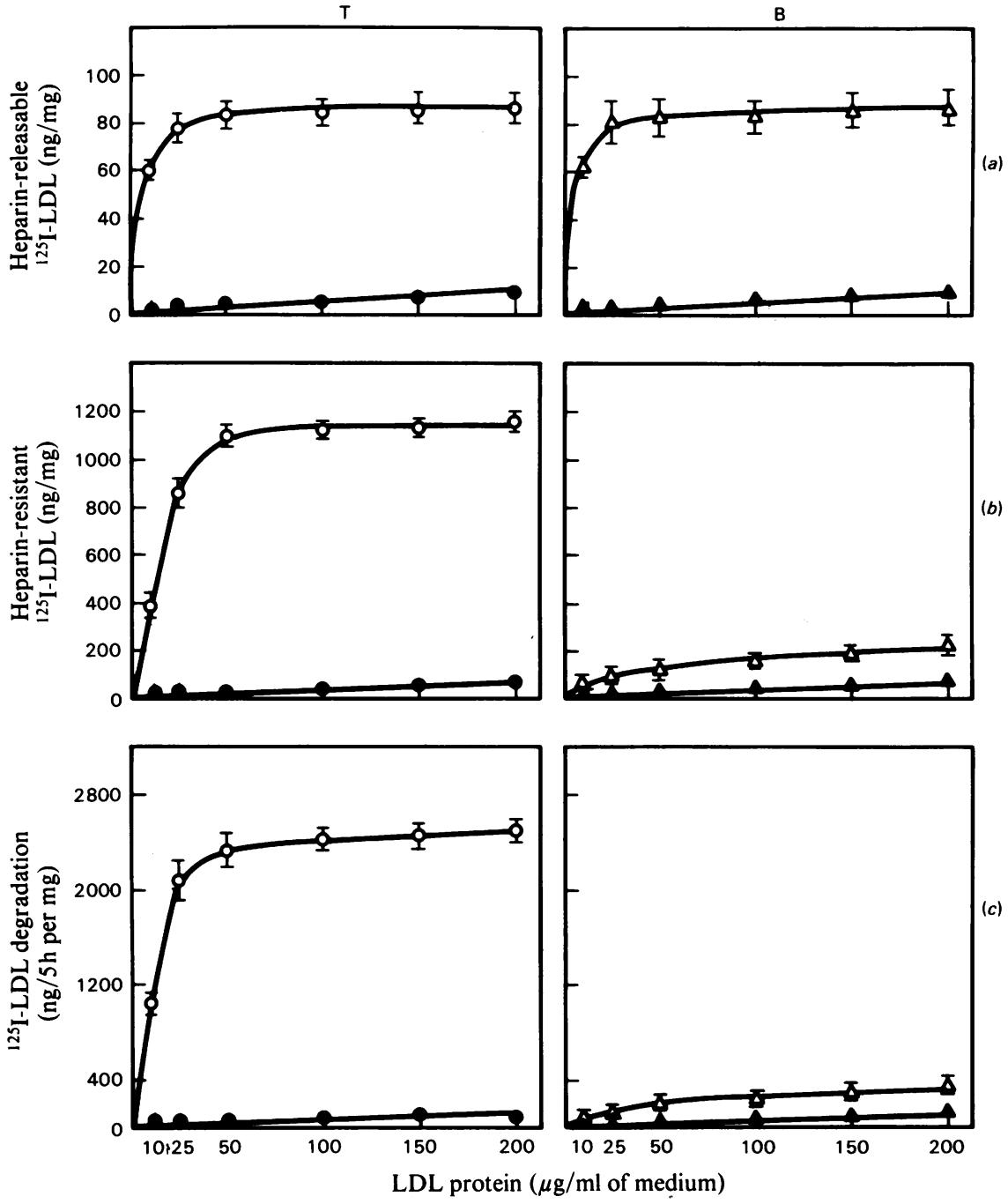

Fig. 1. Cell surface binding (a, heparin-releasable), internalization (b, heparin-resistant), and degradation (c) of ${ }^{125} I-L D L$ in $T$

$(\mathrm{O}, \mathrm{O})$ and $B(\triangle, \triangle)$ lymphocytes following $22 \mathrm{~h}$ incubation in $1 \%$ bovine serum albumin

The closed and open symbols denote non-specific and specific processes, respectively. The data represents analysis using lymphocytes from three subjects. Results are means \pm S.D. The methods are described in the text.

(average $5 \%$ of control) in the presence of a mixture of cholesterol $(24 \mu \mathrm{g})$ and 25 -hydroxycholesterol $(1.2 \mu \mathrm{g})$.

These data demonstrate that the LDL receptor in B lymphocytes possesses the same characteristics as the one in T lymphocytes.

The defective internalization of receptor-bound ${ }^{125}$ I-LDL by B lymphocytes was studied more directly with a timed experiment in which cells that had previously bound ${ }^{125} \mathrm{I}-\mathrm{LDL}$ at $4^{\circ} \mathrm{C}$ were warmed to $37^{\circ} \mathrm{C}$ after removal of unbound ${ }^{125} \mathrm{I}$ LDL by extensive washings, as described in the experimental protocol. The results are presented in Fig. 2. At time zero, the ${ }^{125} \mathrm{I}-\mathrm{LDL}$ bound to both $B$ and $\mathrm{T}$ lymphocytes is virtually identical. In T lymphocytes at $37^{\circ} \mathrm{C}$, the amount of heparin-releasable ${ }^{125} \mathrm{I}$-LDL declines with time. This is associated with an increase in the uptake of ${ }^{125}$ I-LDL by the cells which continues for about $10 \mathrm{~min}$ and declines thereafter. During the same time period, trichloroacetic acid-soluble material begins to accumulate progressively in the medium and continues in a linear fashion throughout the experiment. In contrast, B lymphocytes show minimal, yet detectable, uptake of ${ }^{125} \mathrm{I}-\mathrm{LDL}$ and this is matched by the amount of trichloroacetic acid-soluble material appearing in the medium. The amount of heparinreleasable (bound) ${ }^{125}$ I-LDL declines slowly with 


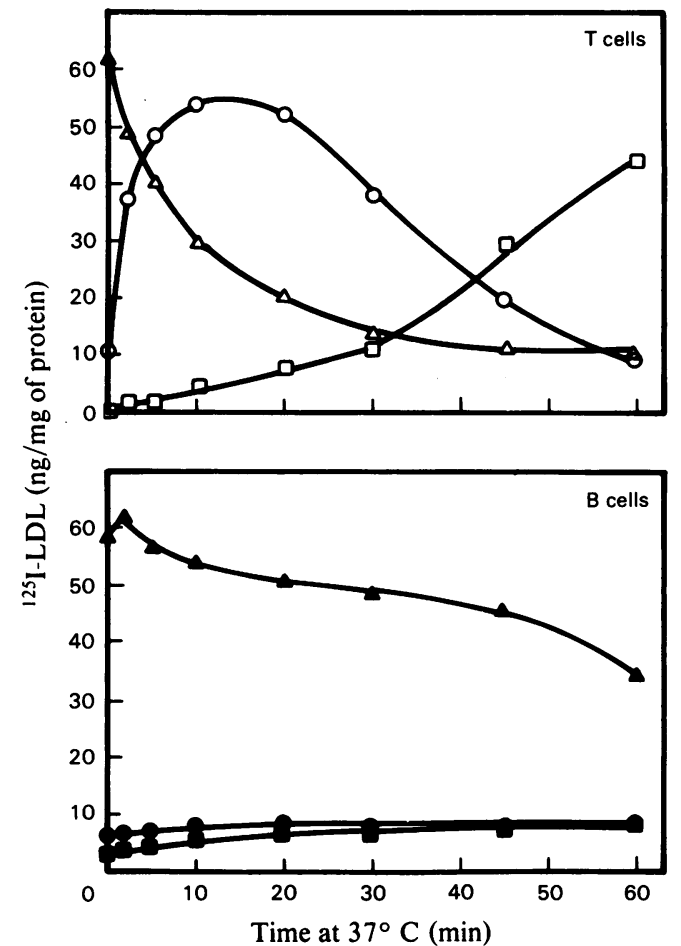

Fig. 2. Kinetics of internalization and degradation at $37^{\circ} \mathrm{C}$ of ${ }^{125} I-L D L$ previously bound to $L D L$ receptor at $4^{\circ} C$ in $T$ and $B$ lymphocytes

After 44-h incubation in $10 \%$ lipoprotein-deficient serum medium, cells were washed twice with culture medium, resuspended in ice-cold medium containing $10 \mathrm{~mm}$-Hepes and $5 \%$ lipoprotein-deficient serum, placed in different wells $\left(2 \times 10^{6}\right.$ cells/well $)$ and ${ }^{125} \mathrm{I}-\mathrm{LDL}(10 \mu \mathrm{g}$ of protein $/ \mathrm{ml} ; 178 \mathrm{c} . \mathrm{p} . \mathrm{m} . / \mathrm{ng})$ was added to each well. Binding was conducted at $4^{\circ} \mathrm{C}$ for $2 \mathrm{~h}$, after which cells were washed and resuspended in $2 \mathrm{ml}$ of medium maintained at $37^{\circ} \mathrm{C}$ which contained $5 \%$ lipoprotein-deficient serum and unlabelled LDL $(10 \mu \mathrm{g}$ of protein $/ \mathrm{ml})$. All wells were incubated at $37^{\circ} \mathrm{C}$. After the indicated interval, the cells were rapidly chilled to $4^{\circ} \mathrm{C}$, the medium was removed, and its content of ${ }^{125}$ I-labelled trichloroacetic acid-soluble material $(\square, \square)$ was measured after the iodine was removed as described in the Experimental section. The amounts of heparin-releasable $(\triangle, \triangle)$ and heparin-resistant $(O, O){ }^{125} \mathrm{I}$ LDL that remained associated with the cells at each time point were determined. time, presumably representing the release of intact ${ }^{125} \mathrm{I}-\mathrm{LDL}$ in the medium.

The fraction of internalized ${ }^{125}$ I-LDL degraded and an internalization index (Anderson et al., 1981) were calculated from studies of binding, uptake, and degradation of ${ }^{125} \mathrm{I}-\mathrm{LDL}$ in $\mathrm{B}$ and T lymphocytes obtained from three healthy subjects. As shown in Table 1, the specific high-affinity binding of ${ }^{125} \mathrm{I}-\mathrm{LDL}$ by the receptor in $\mathrm{T}$ and $\mathrm{B}$ lymphocytes is identical. The uptake, and therefore the degradation, of ${ }^{125}$ I-LDL by the B lymphocytes, however, are disproportionately low; hence, the internalization index for $B$ cell is also low, about $15 \%$ of that for the $\mathrm{T}$ cells. Yet, the fraction of internalized ${ }^{125} \mathrm{I}-\mathrm{LDL}$ degraded by both cells is nearly the same.

It may, perhaps, be argued that the rosetting method may have selectively 'activated' the T cell, enabling it to internalize receptor-bound LDL, without similarly activating the $B$ cell population, which may explain the observed differences. In order to discount this possibility, we carried out an experiment in which one portion of a mixed $(\mathrm{T}+\mathrm{B})$ lymphocyte preparation, from which monocytes were depleted as described under Methods, was subjected to the sheep red blood cell rosetting procedure. Following a $3 \mathrm{~h}$ incubation at $4^{\circ} \mathrm{C}$, sheep red blood cells were lysed without separating $\mathrm{T}$ and $\mathrm{B}$ lymphocytes. Mixed $\mathrm{T}$ and $\mathrm{B}$ lymphocytes thus obtained were washed and cultured for $22 \mathrm{~h}$ in RPMI 1640 medium. A second portion of the above preparation of mixed $T$ and $B$ cells was not subjected to the rosetting procedure but otherwise was treated similarly. The 3hydroxy-3-methylglutaryl-CoA reductase activity in rosetted and unrosetted cells, respectively, was 138 and $133 \mathrm{pmol}$ of mevalonic acid $/ \mathrm{min}$ per $\mathrm{mg}$ of protein. Cholesterol synthesis rates in treated and untreated cells, respectively, were 527 and $511 \mathrm{pmol} / \mathrm{h}$ per $\mathrm{mg}$ of protein in the absence of $\mathrm{LDL}$ in the medium. In the presence of $10 \mu \mathrm{g}$ of $\mathrm{LDL} / \mathrm{ml}$ of medium, reductase activity and cholesterol synthesis in both preparations declined to $20 \%$ of the values obtained in the absence of LDL in the medium. Had the rosetting procedure selectively influenced LDL internalization, the reductase activity and cholesterol synthesis would have

Table 1. Cell surface binding, internalization and degradation of ${ }^{125} I-L D L$ in $B$ and T lymphocytes

Cells were preincubated for $22 \mathrm{~h}$ in RPMI 1640 with $1 \%$ bovine serum albumin. Calculations are based upon binding saturation of ${ }^{125} \mathrm{I}-\mathrm{LDL}$ occurring at $50 \mu \mathrm{g}$ of $\mathrm{LDL}$ protein $/ \mathrm{ml}$. Values are mean \pm S.D., $n=3$.

\begin{tabular}{cccccc} 
Lymphocyte & $\begin{array}{c}\text { LDL bound } \\
(\mathrm{ng} / \mathrm{mg})\end{array}$ & $\begin{array}{c}\text { LDL internalized } \\
(\mathrm{Ag} / \mathrm{mg})\end{array}$ & $\begin{array}{c}\text { LDL degraded } \\
(\mathrm{ng} / 5 \mathrm{~h} \text { per } \mathrm{mg}) \\
(\mathrm{C})\end{array}$ & $\begin{array}{c}\text { Internalization } \\
\text { index } \\
{[(\mathrm{B}+\mathrm{C}) / \mathrm{A}]}\end{array}$ & $\begin{array}{c}\text { Degradation }(\%) \\
{[\mathrm{C} /(\mathrm{B}+\mathrm{C})]}\end{array}$ \\
\hline T & $88.7 \pm 6.2$ & $1280 \pm 15$ & $2665 \pm 93$ & $44.6 \pm 2.4$ & 67.6 \\
B & $87.9 \pm 7.9$ & $216 \pm 4$ & $349 \pm 27$ & $6.5 \pm 0.6$ & 61.8
\end{tabular}


been influenced by LDL only in cells subjected to rosetting and not in the population of cells that were not so treated. Our data show that rosetting procedure has no influence on the process of LDL internalization.

Next, we compared the ACEH and ACAT activities in $B$ and $T$ lymphocytes obtained from five healthy subjects. Again, as mentioned earlier, cells from these donors were studied separately and were not pooled. The ACEH activity was measured immediately upon isolation of the cells from blood (zero time), and again after incubation of cells in $10 \%$ lipoprotein-deficient serum for $44 \mathrm{~h}$. We reasoned that perhaps ACEH activity was modulated in response to the availability of cholesterol esters released in the cell as a consequence of lysosomal hydrolysis of internalized LDL. If so, ACEH activities in cells at zero time should be higher than those measured after cells had incubated for $44 \mathrm{~h}$ in lipoprotein-deficient serum. The first instance represents a situation in which the cells have derived LDL from the circulation which, in turn, is interiorized and degraded by the action of lysosomal enzymes requiring the participation of ACEH. On the other hand, incubation of cells in lipoprotein-deficient serum represents the opposite situation, in which cellular cholesterol exits into the medium, requiring endogenous cholesterol synthesis to be stimulated; the ACEH activity in this condition may be anticipated to be reduced from levels seen in the presence of LDL. In fact, the measured ACEH activities in both $B$ and T lymphocytes after incubation in lipoprotein-deficient serum were very comparable to the levels observed at zero time for the individual cell type. However, as shown in Fig. 3, the B lymphocytes exhibit a considerably lower level of ACEH activity than that observed in T lymphocytes, regardless of whether the cells are in the presence of LDL or are deprived of cholesterol.

The formation of cholesterol $\left[{ }^{14} \mathrm{C}\right]$ oleate as a function of various concentrations of LDL, as shown in Fig. 4, was much lower (about onefourth) in B compared with that in T lymphocytes. Such a difference in cholesterol esterification may be anticipated in view of the above data, which show that LDL is inefficiently internalized in B lymphocytes, and since re-esterification of cholesterol is proportional to the amount of receptormediated LDL degradation. On the other hand, entry into the cell of sterols such as 25-hydroxycholesterol is not known to require a specific receptor. In this case, esterification of 25-hydroxycholesterol in B and T lymphocytes may be expected to be of similar magnitude. However, that this is not the case as shown in Fig. 4; the formation of 25 -hydroxycholesteryl $\left[{ }^{14} \mathrm{C}\right]$ oleate shows only a slight and insignificant increase over that of

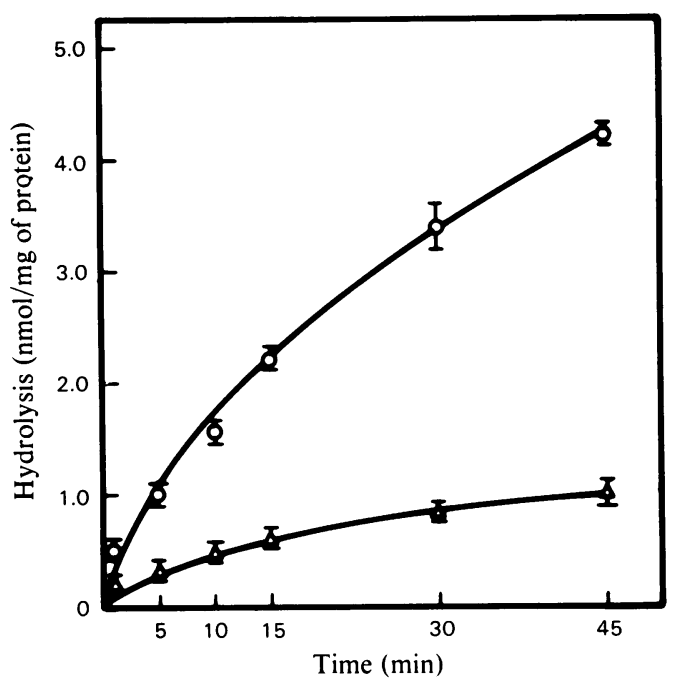

Fig. 3. Determination of $A C E H$ activity in $T(O)$ and $B$ $(\triangle)$ lymphocyte homogenates following $44 \mathrm{~h}$ incubation in $10 \%$ lipoprotein-deficient serum

Data are mean \pm S.E.M. for five subjects. The amount of protein in each assay averaged $8.0 \mu \mathrm{g}$ and $4.5 \mu \mathrm{g}$ for $\mathrm{T}$ and $\mathrm{B}$ lymphocytes, respectively.

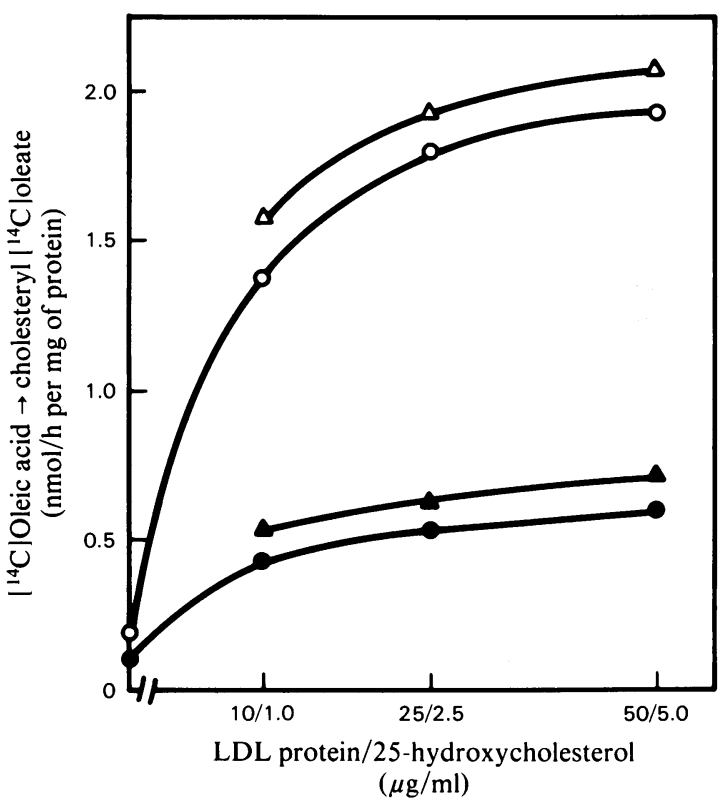

Fig. 4. Effects of increasing concentrations of $L D L(O, O)$ or 25-hydroxycholesterol $(\triangle, \triangle)$ on the rate of incorporation of $\left[{ }^{14} \mathrm{C}\right]$ oleate into cholesteryl $\left[{ }^{14} \mathrm{C}\right]$ oleate by $T(\mathrm{O}, \triangle)$ and $\mathrm{B}(\mathrm{O}, \mathrm{\Delta})$ lymphocytes incubated for $22 \mathrm{~h}$ in $1 \%$ bovine serum albumin

The amount of protein in each well averaged $25 \mu \mathrm{g}$ and $18 \mu \mathrm{g}$ for $\mathrm{T}$ and $\mathrm{B}$ lymphocytes, respectively. The numbers on either side of the solidus represent $\mu \mathrm{g}$ of LDL protein or 25-hydroxycholesterol, respectively. 
cholesteryl ester formation in B lymphocytes. Thus, as with LDL, the magnitude of difference between $B$ and $T$ lymphocytes persists with respect to esterification of 25-hydroxycholesterol as well.

\section{Discussion}

Several results presented here show that LDL receptors in B and $\mathrm{T}$ lymphocytes share a number of characteristics: (i) binding of ${ }^{125}$ I-LDL and saturation kinetics; (ii) binding affinity, as signified by similar $K_{\mathrm{D}}$ of about $4 \mu \mathrm{g} / \mathrm{ml}$; (iii) a high binding specificity, HDL being unable to compete with LDL for binding sites; and (iv) the susceptibility of LDL-receptor activity to feedback regulation by LDL or a mixture of cholesterol and 25-hydroxycholesterol. On the other hand, B cells fail to internalize the receptor bound LDL to any significant extent.

Particularly pertinent to this report is the analysis of both free and esterified sterol content at various times in $\mathrm{T}$ and $\mathrm{B}$ lymphocytes (Table 2 ). When the cells are freshly obtained from the blood, the amounts of free and ester cholesterol are not vastly different in $B$ and $T$ lymphocytes, although there is a suggestion of the possible difference between these cells, as both free and ester cholesterol in B cells are slightly lower than in T cells. Incubation of cells for $22 \mathrm{~h}$ in $1 \%$ albumin results in enhanced cholesterol synthesis, reflected as an increase in free cholesterol, but this change is more noticeable in $\mathrm{T}$ than in B lymphocytes. The crucial difference is in the amount of cholesterol ester

Table 2. Content of free and ester cholesterol in $T$ and $B$ lymphocytes

'Fresh' indicates immediately upon isolation of lymphocytes from blood and separation into $T$ and B cells following depletion of monocytes. Cells were obtained from the blood of eight donors which were then combined. Analyses were by a g.c.-m.s. procedure. $T_{1}$ and $B_{1}$ are cells incubated for $22 \mathrm{~h}$ in growth medium with $1 \%$ albumin and no LDL; $\mathrm{T}_{2}$ and $\mathrm{B}_{2}$ are cells incubated with $50 \mu \mathrm{g}$ of $\mathrm{LDL}$ following incubation in $1 \%$ albumin. Conditions were as described in the text.

\begin{tabular}{cccc} 
& & \multicolumn{2}{c}{$\begin{array}{c}\text { Cholesterol } \\
(\mu \mathrm{g} / \mathrm{mg} \text { of protein })\end{array}$} \\
\cline { 3 - 4 } Lymphocyte & Experiment & Free & Ester \\
\hline $\mathrm{T}$ & Fresh & 34.0 & 2.8 \\
$\mathrm{~B}$ & Fresh & 30.2 & 1.8 \\
$\mathrm{~T}_{1}$ & $22 \mathrm{~h}$ in $1 \%$ albumin & 42.2 & 1.6 \\
$\mathrm{~T}_{2}$ & $+50 \mu \mathrm{g}$ of LDL & 47.3 & 21.3 \\
$\mathrm{~B}_{1}$ & $22 \mathrm{~h}$ in 1\% albumin & 33.3 & 1.4 \\
$\mathrm{~B}_{2}$ & $+50 \mu \mathrm{g}$ of LDL & 34.3 & 2.9
\end{tabular}

formed following incubation of these cells with $50 \mu \mathrm{g}$ of LDL; the more than 10 -fold increase in cholesterol ester content in $\mathrm{T}$ lymphocytes is in contrast to only a 2-fold change in B lymphocytes. This is indicative of almost quiescent LDL receptor activity in B cells following binding, as the ability of LDL to stimulate ACAT activity is considered the most sensitive of the several assays available to assess LDL receptor function in human cells (Goldstein et al., 1975). Table 2 further points to the usefulness of the measurements of free and ester cholesterol content in cells under different conditions to assess LDL receptor activity as a first approximation.

In studies not reported here, we have observed that as little as $0.1 \mu \mathrm{g}$ of 25 -hydroxycholesterol $/ \mathrm{ml}$ of medium is capable of suppressing almost completely 3-hydroxy-3-methylglutaryl-CoA reductase activity and cholesterol synthesis in both $B$ and $T$ lymphocytes. Oxygenated sterols are reported to regulate cholesterol synthesis and reductase activity. If they have a similar role in vivo, it might explain why cholesterol synthesis is suppressed in B lymphocytes to the same extent as in $\mathrm{T}$ lymphocytes at the time of their isolation from blood. However, it is not clear why the ACEH and ACAT activities in B lymphocytes are set at a much lower level in relation to levels in $\mathrm{T}$ lymphocytes.

Finally, the striking similarity between the fibroblasts from subject J.D. (Brown \& Goldstein, 1976) and B lymphocytes as studied here, with respect to binding of ${ }^{125}$ I-LDL to the cell surface receptor and subsequent LDL metabolism, is surprising. These two cell types, J.D. fibroblasts and B lymphocytes, appear to mimic each other in terms of the defect in the internalization of receptor-bound LDL.

We thank Dr. Bruce Rabin for valuable suggestions and Ms. Georgetta Saggio and Ms. Karen Guckert for excellent technical assistance during the course of this work. Mrs. Patricia Arndt provided competent secretarial assistance.

\section{References}

Anderson, R. G. W., Brown, M. S. \& Goldstein, J. L. (1981) J. Cell Biol. 88, 441-452

Belfrage, P. \& Vaughn, P. (1969) J. Lipid Res. 10, 341344

Bilheimer, D. W., Eisenberg, S. \& Levy, R. I. (1972) Biochim. Biophys. Acta 260, 212-221

Bradford, M. (1976) Anal. Biochem. 72, 248-254

Brown, M. S. \& Goldstein, J. L. (1975) Cell 6, 307-316

Brown, M. S. \& Goldstein, J. L. (1976) Cell 9, 663-674

Chao, W. \& Yokoyama, M. M. (1977) Clin. Chim. Acta 78, 79-84

Gal, D., Simpson, D. R., Porter, S. C. \& Snyder, J. M. (1982) J. Cell Biol. 92, 597-603

Vol. 227 
Goldstein, J. L. \& Brown, M. S. (1974) J. Biol. Chem. 249, 5153-5162

Goldstein, J. L., Dana, S. E. \& Brown, M. S. (1974) Proc. Natl. Acad. Sci. U.S.A. 71, 4288-4292

Goldstein, J. L., Dana, S. E., Brunschede, G. Y. \& Brown, M. S. (1975) Proc. Natl. Acad. Sci. U.S.A. 72, 1092-1096

Goldstein, J. L., Basu, S. V., Brunschede, A. Y. \& Brown, M. S. (1976) Cell 7, 85-95

Haley, N. J., Fowler, S. \& de Duve, C. (1980) J. Lipid Res. 21, 961-969

Havel, R. J., Eder, H. A. \& Bragdon, J. H. (1955) J. Clin. Invest. 63, 1345-1353

Ho, Y. K., Brown, M. S., Bilheimer, D. W. \& Goldstein, J. L. (1976) J. Clin. Invest. 58, 1465-1474

Jerrells, T. R., Dean, J. H., Richardson, G. L. \&
Herberman, R. B. (1980) J. Immunol. Methods 32, 1129

Kaplan, M. E. \& Clark, C. (1968) J. Immunol. Methods 5, 131-135

MacFarlane, A. S. (1958) Nature (London) 182, 53

Rabin, B. S. \& Rosenthal, J. T. (1984) Transplantation 37, 616-617

Sanghvi, A. \& Warty, V. (1982) Life Sci. 31, 893-898

Sanghvi, A., Wight, C. \& Warty, V. (1981a) Biochim. Biophys. Acta 665, 48-52

Sanghvi, A., Grassi, E., Bartman, C., Lester, R., Galli Kienle, M. \& Galli, G. (1981b) J. Lipid Res. 2, 720-724

Wornke, R. \& Levy, R. (1980) J. Histochem. Cytochem. 28, 771-776

Wybran, J. H., Carr, M. C. \& Fudenberg, H. H. (1972) J. Clin. Invest. 51, 2537-2543 